\title{
Community Perception of the Green Open Space Planning Aspect in the City of Jakarta
}

\author{
Rustam Hakim Manan ${ }^{1}$ \\ ${ }^{1}$ Department of Landscape Architecture \\ Faculty of Landscape Architecture and Environment Technology- \\ Universitas Trisakti- Indonesia
}

\begin{abstract}
This paper examines the community's perception of green open space planning in the city of Jakarta. The discussion will be divided into two main sections, namely aspects that cause green open space to be less successful and identify the most dominant aspects that hinder green open space planning in terms of planning, institutional, human resources, institutional coordination and funding. The method used is the distribution of questionnaires and interviews. Based on the results of data analysis shows that the dominant aspect in managing green open space in Jakarta is the planning aspect.
\end{abstract}

Keywords: Green open space planning, public perception

\section{INTRODUCTION}

The Jakarta City Government recognizes the need to increase the amount of green open space in the capital. But the success of the increase in the city's green open area on vacant land was followed by the disappearance of the city's green open space elsewhere. The program was less successful because of;

a. Lack of coordination between a number of administrative agencies responsible for Jakarta's green open spaces. The Jakarta Province has a number of institutions responsible only for the city's green open spaces and these responsibilities often overlap between the Parks Department, the Forest Department and the Funeral Department. There is still a lack of common perceptions about the understanding of green open space so that efforts are needed to develop cooperation and clarity of division of authority and work in accordance with their respective main tasks and functions in more depth.

b. Land management plays a very important role in the development of cities, especially large cities that experience rapid economic growth such as the city of Jakarta. Increased economic growth in the region has had the effect of increasing demand for land, both for private sector and government activities. Weaknesses and obstacles for the local government of Jakarta to build public infrastructure such as green open space, collide with the inability to be fully involved in making management of highly complex urban land. Lack of understanding of geography, historical factors, socio-cultural factors that are interrelated with one another, will bring about the impact of reduced attractiveness, and the comfort of the city. Therefore the ability of the development management system, especially in the field of green open space will have a very strategic meaning and nature.

c. There is no land information system model, and an accurate mapping information system that can easily monitor some of the amount of green open space available, some amount removed, and other information that is needed for decision makers and other information needs. This system will be very necessary for the management of the relevant agencies starting from the process of planning, implementation, monitoring to evaluation and control in the context of decision making,

d. There is an ambivalent policy between the central government and the city government. On one hand it recognizes environmental interests, but on the other hand it emphasizes the importance of the economic development sector. Decision makers believe that implementing the concept of sustainability will actually damage economic growth. Therefore when it comes to choosing between maintaining a green open space or giving permission for industrial development, the latter is usually won. One case was the reclamation development on the north coast of Jakarta which damaged the ecological system of the north coast of Jakarta.

e. There is an opinion that green open space is a reserve land to meet the demands of the city's urgent growth. Land requirements for the development of green open space will experience constraints in line with the development of land values, both socially and economically. The lack of legality provisions regarding the regulation, control and supervision that also causes some parts of the city's green open space is used and used improperly.

f. Judicial power is not sufficiently independent. Although the Environmental Protection and Management Act No. 32 of 2009 has been passed, the application of judicial decisions on the destruction of the green open space has not always 
been successful. This is because the judges' understanding and experience of the existence of green open space is still very limited.

There are four elements of management planning that affect urban open space, namely, physical elements (Morancho, 2003), ecological (Costanza , 1997; Li, 2005), participation (Morancho, 2003; Li, 2005) and openness (McGill, 2001; Chakrabarty, 2001). These four elements are described in a number of questions in the questionnaire

\section{METHODOLOGY}

The study will be directed to study the management of Jakarta's green open space in five municipal areas, namely West Jakarta Municipality, East Jakarta Municipality, North Jakarta Municipality, South Jakarta Municipality and Central Jakarta Municipality. The city of Jakarta is a reflection of other cities in the Republic of Indonesia. In the area there are various types of community activities that are closely related to the existence of green open spaces, green open spaces of the city of Jakarta, have green park open spaces, agricultural green open spaces and special green open spaces with management managed by the Parks Department, the Forest Department and the Funeral Department.

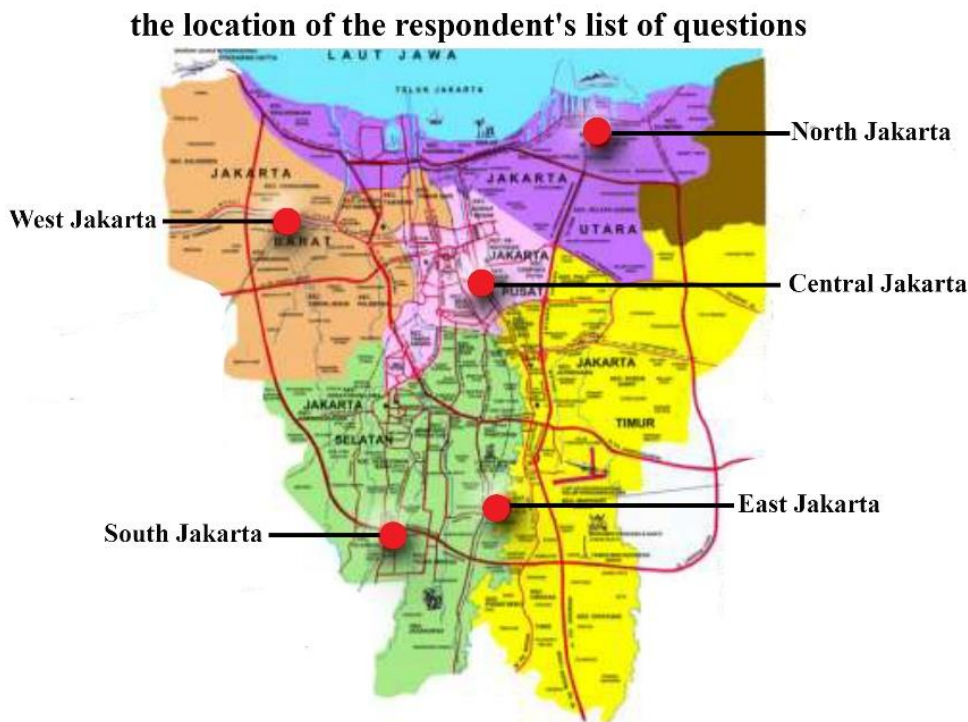

Figure.1. Limitation of the five regions of DKI Jakarta municipality, as Area for Distribution of Question Forms (Source: Field Study, 2018)

Distribution of question forms is done by free sampling technique. This is in line with the statement of Masri Singarimbun (2005) that the sampling type of random sample is taking the unit of analysis freely. In this study the number of samples involved was 260 respondents with 95\% confidence and 5.5\% margin error. These levels are based on estimates and beliefs that have been made by De Vaus (Shuhana, 1997). The selection of this amount is based on the suitability of this study with a $95 \%$ confidence threshold that is still acceptable for validity. Besides this election was also caused by considerations in terms of cost and time factors. To obtain data in processing data, closed questionnaires were used for respondents from the category of policy recipients with 260 respondents from a population of 9,720.40 residents of the city of Jakarta and distributed randomly to five municipal areas, namely the municipalities of Central Jakarta, North Jakarta, South Jakarta, East Jakarta, and West Jakarta, as shown in table 1

Table 1. Distribution of Policy Recipient Respondents

\begin{tabular}{|c|c|c|c|c|c|c|c|c|}
\hline $\mathrm{No}$ & Respondent & $\begin{array}{l}\text { West } \\
\text { Jkt }\end{array}$ & $\begin{array}{c}\text { East } \\
\text { Jkt }\end{array}$ & $\begin{array}{c}\text { Center } \\
\text { Jkt }\end{array}$ & $\begin{array}{c}\text { South } \\
\text { Jkt }\end{array}$ & $\begin{array}{c}\text { North } \\
\text { Jkt }\end{array}$ & $\begin{array}{c}\text { Position } \\
\text { Respondents }\end{array}$ & $\begin{array}{c}\text { Amount } \\
\text { Respondents }\end{array}$ \\
\hline 1. & $\begin{array}{l}\text { Scientific Society / } \\
\text { University }\end{array}$ & \multicolumn{5}{|c|}{$\begin{array}{l}\text { Univ. Trisakti, West Jakarta } \\
\text { Univ. Borobudur, East Jakarta } \\
\text { Univ. Indonesia, Central Jakarta } \\
\text { Indonesian Institute of Technology } \\
\text { South Jakarta } \\
\text { Univ. Tarumanegara, North Jakarta }\end{array}$} & $\begin{array}{l}\text { Policy } \\
\text { Recipients }\end{array}$ & 60 \\
\hline 2. & $\begin{array}{l}\text { Professional } \\
\text { Society }\end{array}$ & \multicolumn{5}{|c|}{$\begin{array}{l}\text { Professional Organizations } \\
\text { ISLA (Indonesia Society of Landscape Architects) } \\
\text { IAI (Indonesia Architects Institution) } \\
\text { ILCA (Indonesia Lanscape Contractors } \\
\text { Association) }\end{array}$} & $\begin{array}{l}\text { Policy } \\
\text { Recipients }\end{array}$ & 30 \\
\hline
\end{tabular}




\begin{tabular}{|l|l|l|l|l|l|l|l|c|}
\hline 3. & $\begin{array}{l}\text { Jakarta City } \\
\text { Community }\end{array}$ & 15 & 15 & 15 & 15 & 15 & $\begin{array}{l}\text { Recipients of } \\
\text { Policies }\end{array}$ & 75 \\
\hline 4. & $\begin{array}{l}\text { Non-Governmental } \\
\text { Organization or } \\
\text { NGO }\end{array}$ & \multicolumn{2}{|l|}{$\begin{array}{l}\text { The Indonesia Transparency Society } \\
\text { The Indonesian Green Foundation }\end{array}$} & $\begin{array}{l}\text { Policy } \\
\text { Recipients }\end{array}$ & 20 \\
\hline 5. & $\begin{array}{l}\text { Community of } \\
\text { Business World / } \\
\text { Traders, }\end{array}$ & 15 & 15 & 15 & 15 & & $\begin{array}{l}\text { Recipients of } \\
\text { Policies }\end{array}$ & 75 \\
\hline & & & & & & TOTAL & 260 \\
\hline
\end{tabular}

The assessment of policy recipient perceptions was developed through a questionnaire which covered issues involving the following five variables: 1) planning; 2) institutional; 3) human resources; 4) coordination and 5) funding.

\section{DISCUSSION}

To answer the study relating to the study of management aspects that may contribute to the success of green open space management, the authors have conducted an analysis of the data obtained rather than a study of the question forms and interview studies., institutional aspects, aspects of human resources, aspects of coordination and aspects of funding, as illustrated in Figure 2 below

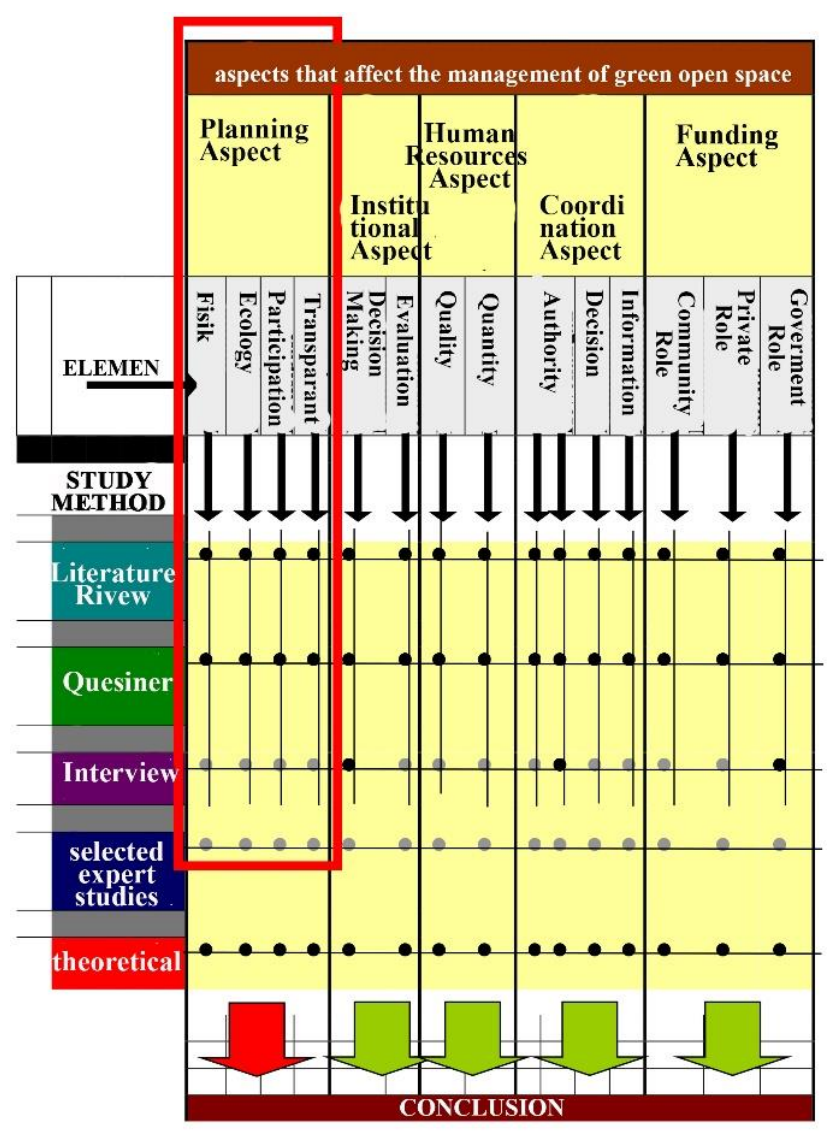

Figure 2. Chart for Comparing Management Aspects in the study (Source: Investigator, 2018)

\section{a. Physical Elements in the Planning Aspect}

Based on the results of the questionnaire in terms of planning aspects, it was found that the people of Jakarta agreed (59 percent) who stated that the factor of physical space limitations was an obstacle in planning. This is due to the reduced area of green open space that can be achieved by the DKI Jakarta government. Meanwhile, most people do not agree if the existing open space is transferred to be used for other uses or functions. The number of people who do not agree to the transfer of this function reaches 92 percent. The transfer of functions makes the quantity of green space decreases. To increase the quality of green open space, the community generally agreed to plant their yard with trees to improve the local ecosystem. 


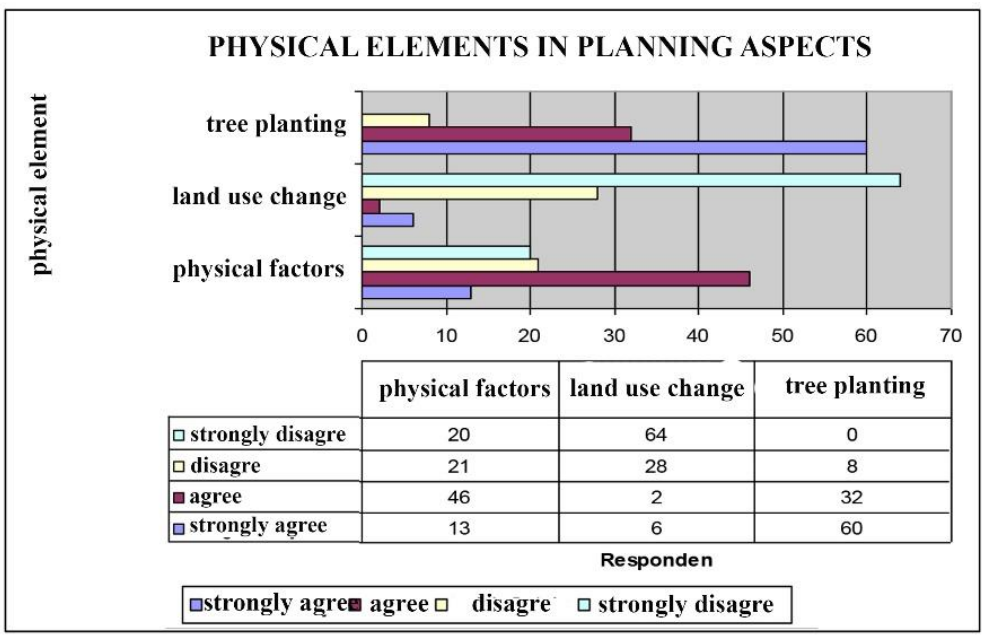

Figure 3. Physical elements in the planning aspect

The relationship between the decline in green open space and the transfer of functions can be said to be very close. In general, the decrease in the amount of green open space is caused by a change of function Based on the comparison between the two physical elements, it can be concluded that in this case the residents of Jakarta expect no change in the function of green open space which results in a decrease in the number. This is consistent with research conducted by Morancho (2003) which states, there is a similar relationship between the function of urban green open space with the physical quality of the city.

\section{b. Ecological Elements in Planning Aspects}

The ecological element is an important factor in the planning aspect. This can be seen from the perception of green open space people who agree on the importance of green open space as forming the ecological quality of the city. Judging from the four questions raised concerning ecological aspects, ecological balance is a major factor. This means that the main use of the existence of green open space according to public perception is as a balance of the city's ecosystem. This can be seen from the percentage who strongly agreed and agreed to reach 100 percent. Other ecological elements that stand out and are felt by the community are air and visual pollution (strongly agree and agree 90 percent). Air pollution is the most felt factor due to an imbalance in the city ecosystem. The element of air pollution has the second rank after the awareness of ecological balance. Both of these can be seen in Figure 4

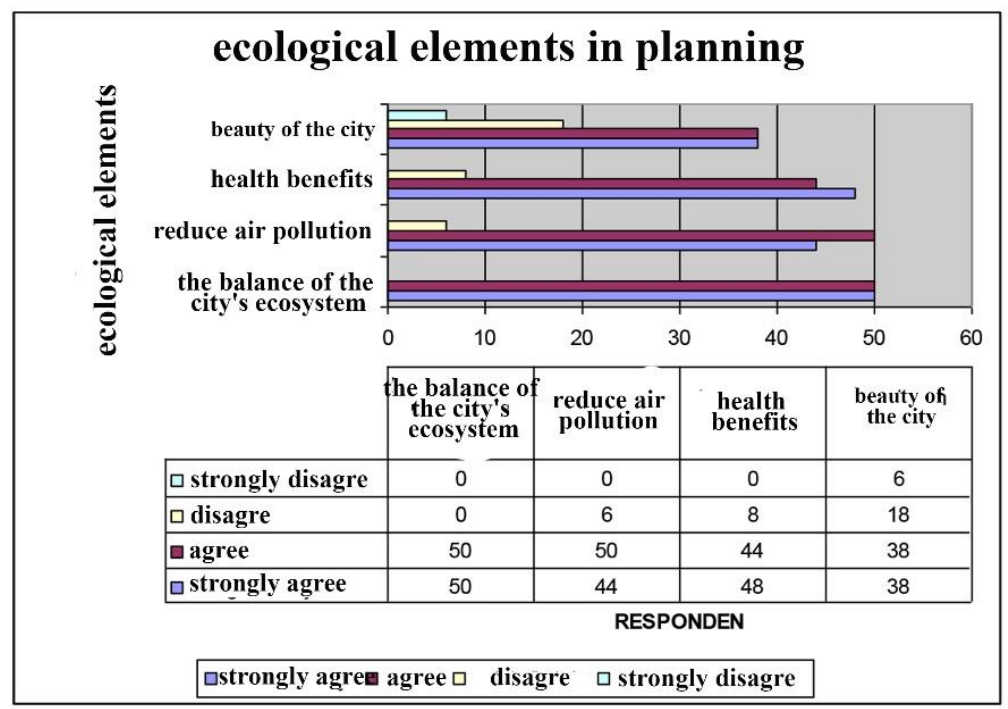

Figure 4. Ecological elements in planning aspects

The first component (equilibrium) and the second (air pollution) is one of the forms of causal relations, this is supported by the third and fourth components as the dominant component perceived by the community, namely the decline of ecosystems and understanding the importance of ecological functions. The beauty component of the city has the smallest percentage related to the level of public understanding of the visual function of the city to give the image of Jakarta as the nation's capital. If related to previous research by $\mathrm{Li}$ et al. (2005) who developed a comprehensive conceptual framework for green open space in China 
based on the principles of landscape ecology. So the main thing to do is in the aspects of green space planning is to establish a green open space master plan for the city in a long-term, sustainable and characteristic of the city of Jakarta. With the results of the questionnaire above, the priority that must be done to maintain the balance of the city's ecosystems is to improve the quality of the existing Jakarta city landscape, prevent the reduction in the amount of open space and try to increase the quantity of green open space, so that the ecological function of the city can be fulfilled.

\section{c. Elements of Participation in the Planning Aspect}

Community participation is a key element of green open space planning and maintaining its quality. The aspect of planning in the management of urban green open spaces based on community perceptions concerning things that smell of bureaucracy means that up to now the aspects of planning green open spaces have not been socialized by the local government to the community. Thus the government is more likely to implement a top down or central planning process than bottom up which accommodates the wishes of the community. This can be seen from the percentage of public perceptions that have received planning socialization from the government only reaching 20 percent, only a small portion of the public has ever been consulted (public hearing) of 28 percent. The unclear role of the community is still unclear, so there is a striking difference between the ever and never external factors in this case the community in urban green open space planning. When compared with previous research conducted by Breuste (2004), planning will be efficient if it involves the community together. Branch (1970) emphasizes that planning must be evaluated continuously and flexibly in urban green open space planning. In certain areas, there is indeed government authority to plan green open spaces, but in a wider area, community involvement is essential so that the planning is in accordance with the needs of the community and faces the complexity of city growth.

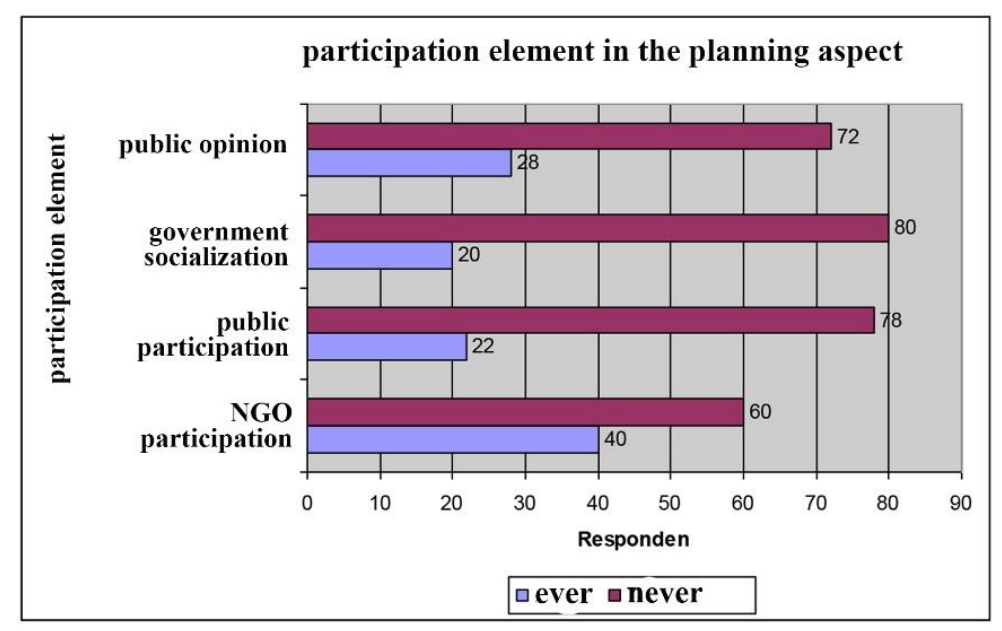

Figure 5. Elements of participation in the planning aspect

Based on the results of the questionnaire concerning the element of participation it appears that the involvement of NonGovernmental Organizations (NGOs) is clearer than the involvement of the community. This shows the role of NGOs in Jakarta in planning green open space is quite useful and calculated. Community involvement is still lacking in terms of the percentage of responses and scoring aspects requested in green open space planning. As many as 72 percent of the community felt they were never asked for their responses and opinions for green open space planning. This means that community participation is representative and not individual. This is related to the planning system which still needs to be improved regarding how the involvement of the community can be thoroughly represented. Is the use of information technology that allows the community to give active advice or by giving awards for community participation.

\section{d. Elements of Openness in Planning Aspects}

The element of openness is one aspect of planning, especially in this era. The community has begun to realize and demand openness of the government, especially in managing the city. This can be seen from the respondents' opinions about the openness of bureaucratic attitudes and the dissemination of information on green open space planning in the city of Jakarta. Based on the openness element of the bureaucratic system, it can be seen that 86 percent of the people agreed to this. Whereas in the information element 72 percent of the public strongly agreed and agreed on information disclosure. Judging from this percentage, it can be noted that the community has begun to be critical of the openness of the plan and not just information, which means that there must be more explanation for green open space planning. 


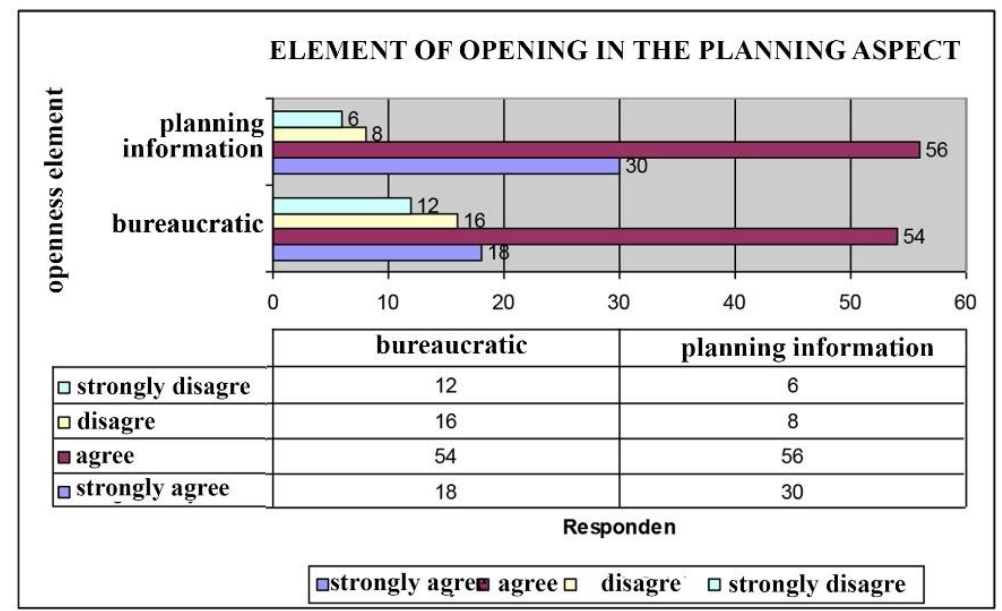

Figure 6. Elements of openness in planning aspects

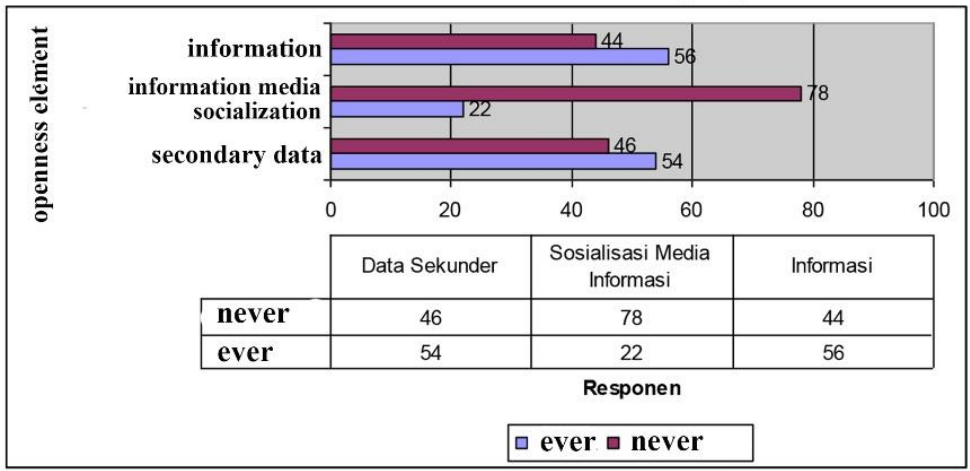

Figure 7. Elements of openness in planning aspect

Based on the results of the questionnaire, it appears that the main obstacle in the openness of aspects of green open space planning is socialization. The aspect of information media socialization can be said to be lacking because almost 78 percent of respondents said there was never any socialization of plans through information media. Although on the aspect of information almost 56 percent said they had heard of green open space planning. This is supported by the fact that most respondents have faced problems in finding secondary data about green open space plans in the city of Jakarta. This means that the information is quite adequate but a deeper explanation of the planning aspects is still not open. Based on the above results, if it is associated with research conducted by Chakrabarty (2001), the equation that exists is the ability of social reaction and social evaluation in urban green open space planning. This means that the community has been critical in the attitude of reaction and evaluation of the city green open space management plan. This requires the government as an urban planning actor to not only disseminate information but require socialization, so that government intervention and regulations have greater freedom and flexibility in improving the overall performance of the urban sector.

\section{CONCLUSION}

The existence of Jakarta's green open space is very much determined by the plan. The responsibility for planning the green open space should ideally be carried out jointly between the city government, the private sector and the community. This research tries to explore aspects of green open space planning such as what is expected by the community. To limit these aspects, a study of previous research related to green open space planning was conducted. Based on previous studies it can be concluded that aspects of green open space planning include aspects of physical, ecological, participation and openness. These aspects are elaborated in the form of questionnaire questions and distributed to the public to find out their understanding and views on aspects of green open space planning in the City of Jakarta.

Clarity of elements in the planning aspect is the main outcome of this research. These aspects include supporting elements in the clearest sequence as follows: ecological elements, physical elements, openness and participation. In a more detailed component the influential ecological elements include ecological balance, air pollution, ecological quality degradation, ecological functions and finally technology. While the physical elements include a decrease in the number and conversion of land. In the openness element, the obvious component is planning and information. Lastly is the element of participation which includes the bureaucracy and the community. 


\section{REFERENCES}

[1] Morancho., Aurelia Bengochea. ). "A Hedonic Valuation of Urban Green Areas”, Journal Landscape and Urban Planning 66, (2003) pp 35-41.

[2] Costanza, R., d’Arge, R., de Groot, R., Farber, S., Grasso, M., Hannon, B., Limburg, K., Naeem, S., O’Neill, R.V., Paruelo, J., Raskins, R. G., Sutton, P., Van den Belt, M. “The Value of the World's Ecosystem Services and Natural Capital”. Journal Nature 387, (1997) pp 253-260.

[3] McGill, R. "Urban Management Checklist", Journal Cities 18 (5), (2001) pp 347-354

[4] Chakrabarty, B. K. (2001). "Urban Management: Concepts, Principles, Techniques and Education”, Journal Cities 18, (2001) pp 331-345.

[5] Singarimbun, Masri. dan Handayani "Metode Penelitian Survey”, Yogyakarta: Gajahmada University Press. . (1989).

[6] Shuhana Shamsuddin, and Bashri, A. S. "Public Perception of Urban Spaces - A Case Study Centre of Bandaraya Johor Bahru". Unpublished Research Report. Skudai, Johor Bahru: Jabatan Seni Bina, Fakulti Alam Bina. Universiti Teknologi Malaysia. (1999).

[7] Li, F., Wang R., Paulussen J., Lui X. "Comprehensive Concept Planning of Urban Greening Based on Ecological Principles: a Case Study in Bejing, China". Journal Landscape and Urban Planning 72 (4), (2005). pp 325-336.

[8] Breuste, Jurgen H. Decision Making, "Planning and Design for The Conservation of Indigenous Vegetation Within Urban Development", Journal Landscape and Urban Planning 68, (2004) pp 439-452.

[9] Branch, M C. "Delusions and diffusions of city planning in the United States". Management Science 16 (12). (1970)

[10] Abbot, John. "Sharing the City, Community Participation in Urban Management", Earthscan Publication, London. (1996)

[11] Adolf Heuken SJ, "Historical Sites in Jakarta", Cipta Loka Caraka Foundation, Jakarta. (1997).

[12] Butler Jd \& James Rf, "Landscape Management", Van Nostrand Reinhold Co., New York, (1988),

[13] Weimar, David.L and Aidan R. Vining. "Policy analysis. Concepts and practice”. Prentice-Hall International, Inc. New Jersey. (1989),

[14] White, Rodney R, “Urban Environmental Management”, John Wiley, New York. (1994) 